Anders Hellström

\title{
How anti-immigration views were articulated in Sweden during and after 2015
}

MIM Working Paper Series 21: 2

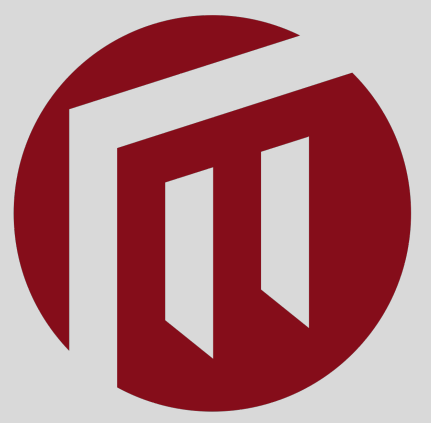


MIM Working Paper Series No 21: 2

\section{Published}

2021

\section{Editor}

Anders Hellström, anders.hellstrom@mau.se

\section{Published by}

Malmö Institute for Studies of Migration, Diversity and Welfare (MIM)

Malmö University

20506 Malmö

Sweden

ISBN 978-91-7877-193-6 (pdf)

DOI 10.24834/isbn.9789178771936

Online publication 


\section{How anti-immigration views were articulated in Sweden during and after 2015}

\section{ABSTRACT}

The development towards the mainstreaming of extremism in European countries in the areas of immigration and integration has taken place both in policy and in discourse. The harsh policy measures that were implemented after the 2015 refugee crisis have led to a discursive shift; what is normal to say and do in the areas of immigration and integration has changed. Anti-immigration claims are today not merely articulated in the fringes of the political spectrum but more widely accepted and also, at least partly, officially sanctioned. This study investigates the anti-immigration claims, seen as (populist) appeals to the people that centre around a particular mythology of the people and that are, as such, deeply ingrained in national identity construction. The two dimensions of the populist divide are of relevance here:

The horizontal dimension refers to articulated differences between "the people", who belong here, and the "non-people" (the other), who do not. The vertical dimension refers to articulated differences between the common people and the established elites.

Empirically, the analysis shows how anti-immigration views embedded in processes of national myth making during and after 2015 were articulated in the socially conservative online newspaper Samtiden from 2016 to 2019. The results indicate that far-right populist discourse conveys a nostalgia for a golden age and a cohesive and homogenous collective identity, combining ideals of cultural conformism and socio-economic fairness.

\section{Key Words}

Anti-immigration claims, Sweden, refugee reception crisis, national myths, discursive shift, populism, the people, Samtiden 


\section{Acknowledgement}

This working paper is based on a report written in the project NoVaMigra (Norms and Values in the European Migration and Refugee Crisis). I hereby acknowledge the financial assistance and the intellectual support that this endeavour has given me. In the process of developing this report into a working paper, I have benefited from a mutual dialogue with students in courses on Populism and Democracy at both the bachelor and master levels in International Migration and Ethnic Relations at Malmö University - my sincere appreciation. For final language editing, I am also very grateful for all the valuable comments made by Jasmin Salih.

\section{Bio Notes}

Anders Hellström is an associate professor in political science and a senior lecturer in IMER. He is an affiliated member of the research institute Malmö Institute for Studies of Migration, Diversity and Welfare (MIM) at Malmö University. His research interests include discourse theory and representation of migration, populism, and nationalism. He has published widely in such academic journals as Government and Opposition, Journal of International Migration and Integration, and Ethnicities. His most recent monograph is Trust Us: Reproducing the Nation and the Scandinavian Nationalist parties. His most recent anthology is Nostalgia and Hope: Intersections between Politics of Culture, Welfare, and Migration in Europe together with Ov. Cristian Norocel and Martin Bak-Jørgensen.

\section{Contact}

Anders.hellstrom@mau.se 


\section{PROLOGUE}

In 1913, a government report on emigration was conducted in Sweden. The purpose behind it was to support the government in proposing measures to halt the mass emigration to the United States by implementing a series of social reforms to improve the living conditions for the natives (Hellström 2016: 34, Hall 1998). By 1900, approximately one-fifth of the total Swedish population had emigrated to the United States (Persson and Arvidsson 2012: 184). The migrants fled from misery, despair, oppression, and starvation in the pursuit of a better, or at least a liveable, life. Today, the memories of emigration have faded away. The decision to move from Sweden is today rather based on personal aspirations, to perhaps "seek an adventure" (Suter 2019), not on impoverishment or fear for one's own life. Sweden is today a country of immigration, not emigration.

Migration to Sweden has been substantial over the past five decades. By the end of 2018, more than 19 per cent of the Swedish population was foreign born. In 2015, there was a considerable growth in the number of asylum-seekers - from around 30,000 per year to over 160,000 during just three months in the autumn. These demographic transformations have instigated polarized sentiments in the national population.

In 2021, the public discussion remains heated. However, the discursive tone has changed. The political language in the area of immigration politics has shifted from offering proud declarations of universal hospitality to presenting Sweden as a country that is not hospitable for prospective asylum seekers at all. That is, they should not come here. Furthermore, the immigration issue is no longer framed around how Sweden can best serve as a safe residence for those who escape war and torture; rather, it is framed conversely around how immigration can best be made beneficial for Sweden, as argued by the party leader of the largest mainstream-right opposition party in April 2021 (Dagens Nyheter 7 April 2021; cf. Dagens Arena 8 April 2021). ${ }^{1}$

\section{AIM}

The development towards the mainstreaming of extremism in European immigration politics has in the scholarly literature been referred to as a discursive shift - the borders of what is normal to say and do have shifted (see e.g. Wodak 2019). In this paper, I ask how anti-immigrant arguments were articulated in Sweden in the context of the refugee reception crisis during the autumn of 2015.

What the nation is represented to be has changed following this discursive shift. I here show how anti-immigration views were embedded in a national identity

\footnotetext{
${ }^{1}$ In Denmark, this development towards a mainstreaming of extremism has gone even further than in Sweden, and it is no longer possible to clearly see the difference between mainstream and extremism (see also e.g. Aftonbladet 12 April 2021).
} 
construction that centred around a particular mythology of the people. This focus conforms to the horizontal dimension of the populist divide, which refers to how the people are depicted in relation to the non-people, those who do not naturally belong to the nation. ${ }^{2}$

In this study, I see populism as a communication strategy that concern appeals to the people (see e.g. Canovan 1999) by various political actors. This is akin to what Moffit (2020) refers to as the discursive-performative analytical tradition in the study of populism. Thus, I move away from a focus on who is a populist actor or whether it is, for instance, good or bad for democracy (see e.g. Mudde \& Kaltwasser 2012) to focus instead on the populist discourse: how anti-immigration claims are communicated in national myth making.

\section{OUTLINE OF THE STUDY}

I begin with offering a short background section on recent policy changes in Swedish immigration policy and the discursive landscape where previous extreme views have been embedded in the political mainstream. This provides the backdrop of the discursive shift in Swedish immigration politics. Thereafter, I proceed with a discussion on how the opposition to immigration has repercussion on national identity construction conceptualized as national myth making. The empirical analysis is based on an operationalization of national myths in three separate categories: golden Age, identity, and conflict. In the analysis, I explore how populist discourse generally uses national myths as appeals to the people; I do so through scrutinizing articles on the concept of national identity in the socially conservative online newspaper Samtiden from 2015 to 2019.

\section{POLICY CHANGES IN SWEDISH IMMIGRATION POLITICS ${ }^{3}$}

From the Second World War to the mid-1970s, immigration to Sweden was largely attributable to the high demand for foreign labour in the growing industrial and service sectors. In this period, only a minor portion of immigrants were refugees from nonEuropean countries. In the last ten years, immigration to Sweden has reached an alltime high. Figures during these recent years have vastly exceeded the earlier peaks of immigration to Sweden in the late 1970s and during the Yugoslavian Civil War in the early 1990s (Bevelander 2011).

\footnotetext{
${ }^{2}$ The vertical dimension of the populist divide refers to the opposition between the people and the elite (see e.g. Brubaker 2020). This distinction will be further elaborated on below in the text.

${ }^{3}$ The information in this section is collected from Bevelander \& Hellström (2019).
} 
Figure 1. Number of Asylum Seekers in Sweden 2000-2017

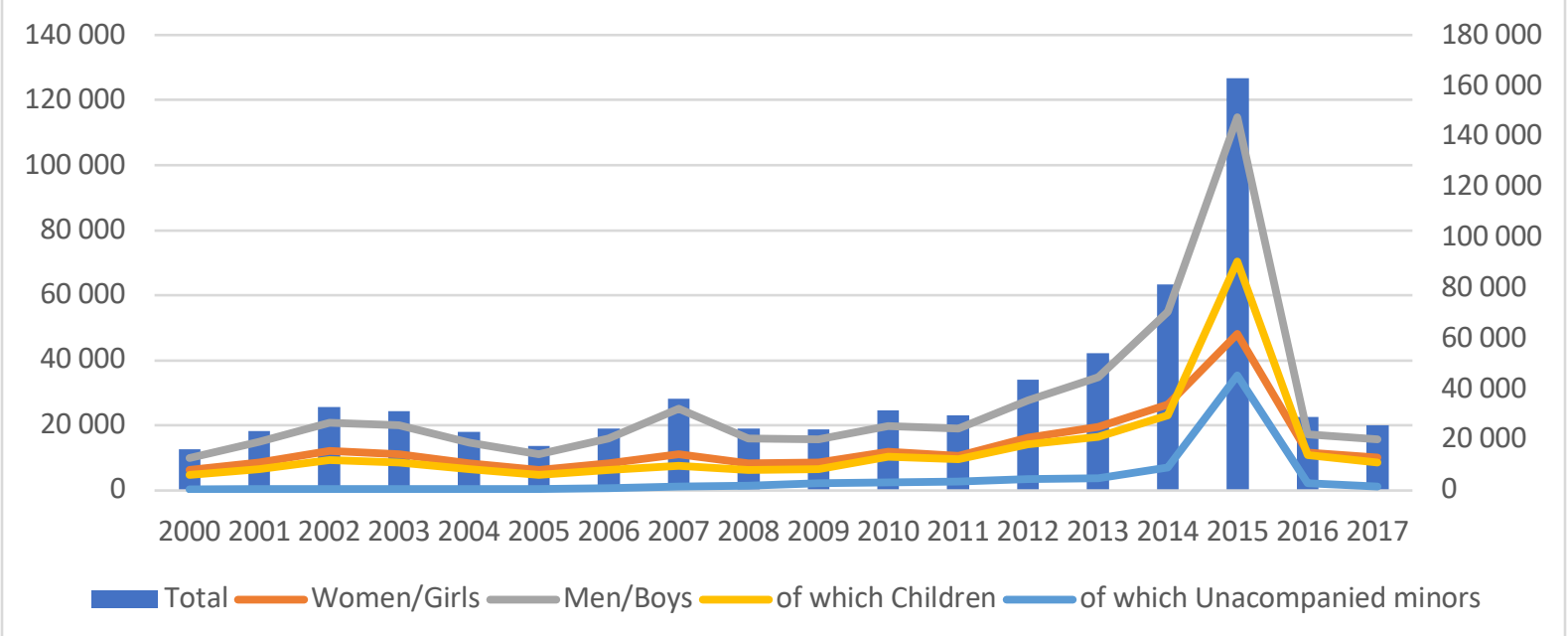

Source: Bevelander \& Hellström (2019: 79).

The number of asylum seekers to Sweden was high in 2015. Taken by surprise, the Swedish Migration Agency had to partially rely on civil organizations and municipalities for help in arranging the reception of these asylum seekers in the first days following their arrival (Bevelander \& Hellström 2019: 76). The initial feelings of empathy and collective willingness to assist in the public ${ }^{4}$ were soon accompanied with concerns and on criminality, segregation, illegality and so forth. This development of this discussion is the contextual background to what I henceforth refer to as a discursive shift in Swedish immigration politics.

In November 2015, several new policies were passed to discourage asylum-seekers from coming to Sweden in order to give the country the "breathing space" that it needed to handle the large number of asylum cases (SOU 2017: 12). The overarching aim was to adopt temporary rules that would abide only by the "EU minimum" standards so that asylum-seekers would be encouraged to seek refuge elsewhere. It should be noted that resettled refugees were not affected by any of these changes in policy, as the modifications only applied to asylum-seekers.

On 12 November 2015, the concept of temporary border and ID controls was introduced for the first time since Sweden entered the Schengen Agreement in 1995, with police requesting identification of all persons entering Sweden, whether by train, bus, or boat. Individuals were required to either immediately request asylum in Sweden

\footnotetext{
${ }^{4}$ The iconic image of the dead Syrian refugee child, Alan Kurdi, in the arms of a coast guard was disseminated in many news outlets over the world. This image represented the tragic outcome of a deplorable and devastating immigration politics in many European countries, manifested by an emotionless and cynical border guard policies with deaths of refugee children as tragic results. This image spurred many solidarity movements in many places in Europe, but it was later replaced with demands of tighter and tougher immigration policies in many European countries.
} 
- thus preventing them from doing so later in another country - or turn back. The border controls went into effect on 4 January 2016 .

On 24 November 2015, when the government proposed a temporary law that stated that all asylum-seekers who applied after that date could only receive temporary, rather than permanent, residency if it were granted in Sweden. Under these new rules, each asylum-seeker's temporary residency is to last three years or 13 months and can be extended beyond that time if the person still requires protection.

These policy changes were by some in the electorate a welcome and even a necessary adjustment of the recent, comparatively generous immigration policies. On 18 October 2019, the Social Democratic Minister of Justice and Migration, Morgan Johansson, said that we shall not return to the refugee situation in 2015 (S venska Dagbladet 21 January 2019). When representatives of the political mainstream signal to the voters that they have lost control of the situation, this enables previously extremely hostile attitudes towards immigrants to appear more credible, more mainstream. Opinions that were previously considered extreme are now considered normal. The suggested policy changes have implications both on actual policy making and on how these are framed. Extremism has become mainstream.

\section{THE MAINSTREAMING OF EXTREMISM}

Academic discussions have devoted much attention to the development of the mainstreaming of the radical right (See e.g. Bevelander \& Wodak 2019). The slow democratic decay across Europe, which accompanied the access to power of right-wing populist and anti-immigration parties, and even the descent into authoritarianism in several less consolidated democracies (Norocel et al. 2020) and in countries in Western Europe - these developments indicate that traditional mainstream parties, both conservative and social democratic, are increasingly open to introducing policies that were previously limited to the populist radical right.

The development towards authoritarianism in the party-political field has changed how we approach issues of immigration and integration in public debate. As the policies of the populist parties are being normalized, so is the populist discourse.

In the choice between paying allegiance to international norms of international solidarity and securing the national borders, the choice in Sweden veers towards the latter (see Hampshire 2013). However, in the past, the public opinion had gradually grown to become less negative, and the negative views were neither particularly salient to determine voter choice nor channelled via any traditional parties (Demker 2014). The Swedish anti-immigration party, the Sweden Democrats (SD), did not obtain enough support to enter into the national parliament until 2010. Thus, for a long time, Sweden was seen as a deviant case (Dahlström \& Esaiasson 2011). However, this development came to a final halt in 2015, as explained above. What was once referred 
to as "Swedish exceptionalism" was no longer the case (see also e.g. Emilsson 2019; Rydgren and Van Meiden 2019). ${ }^{5}$

In his recent book on the far right, the scholar on populism Cas Mudde (2019) distinguishes between four waves in the historical development of the far right. The first wave refers to the development of the neo-fascist parties after the end of the Second World War, 1945-1955. Several of these parties and movements were banned and generally attracted only a few extremists on the fringes of the political spectrum. The second wave - labelled as right-wing populism - lasted between 1950 and 1980 and included the emergence of reactionary movements in, for example, France, Denmark, and Norway to stand up for the little man against the state.

Mudde (2019) talks of a third wave that arose in the 1980s consisting of various radical parties. Neo-liberal economic policies against the state were combined with cultural protectionism, which was referred to as the winning formula (Kitschelt \& Mcgann 1997). This wave had different manifestations in different countries, depending on the elite against which you are rallying. Conceptually, it is possible to distinguish between different kinds of elites. The political elite generally represent the mainstream political parties in their respective countries. The media elite are the traditional media and public service. Based on a conviction that these sources of information disseminate fake news and hide the "real truth" from the citizens, the populists tend to seek information elsewhere in social media (e.g. in Facebook groups which tell the truth). The economic elite are the privileged few who earn much more money than the common man and do not reside in the same districts but live in their ivory towers. During the COVID-19 pandemic, the economic elite, typically, can work from home and do not risk unemployment. The moral elite refer to those who espouse politically correct knowledge instead of relying on common sense knowledge. They believe they know what is best for you, even if this contradicts popular wisdom. Empirically, the different elites look different in different countries:

In the welfare-rich Scandinavian countries, the populist parties are likely to rally against e.g. high taxes and state intervention in the economy. As a contrast, in countries such as Belgium, Italy and Switzerland with dense regional divisions and ethnic tensions, the populist resistance is more likely to emphasize regional independence. In other countries, such as France and Germany, immigrants risk becoming scapegoats and framed by the general public as the direct cause of relative economic deprivation and cultural alienation. (Taggart 200: 76, quoted in Hellström 2016: 172)

Despite their many differences and the failure to communicate a joint common message, the populist parties and movements in the third wave could all be seen as

\footnotetext{
${ }^{5}$ Some would argue that Sweden already stopped being exceptional when the SD crossed the parliamentary threshold in 2010 (Strömbäck et. al. 2016).
} 
normal pathologies and normal counter-reactions ${ }^{6}$ on the route towards infinite progress with endless technological achievements. ${ }^{7}$

The emergence of the fourth wave in the 2000s, representing the current far-right situation, sets itself apart from the previous waves, Mudde (2019) explains. By now, the far-right parties are fully normalized and embedded in the mainstream political discourse (Mudde 2010; Mudde 2014; Bergmann 2017; Hellström \& Bevelander 2018; Rydgren 2018; Mudde 2019; Akkerman et al. 2019). Mainstream politics is today imbued by certain "politics of fear" (Wodak 2015).

In a recent study of discursive shifts in Poland, Krzyżanowski (2021) describes the process through which it has become normal to talk about immigrants and refugees in a derogatory way. The topic of immigration as an immediate danger and immanent threat was initially enacted then diffused and perpetuated in Polish political discourse. It has now become normalized, setting up new social values "while being strategically 'clad' in quasi politically correct and acceptable themes, arguments and statements" (Ibid: 7). The Polish example shows that anti-immigration claims in public opinion, the media, and the judiciary and harsh policy measures can be implemented also in areas where there are hardly any immigrants. ${ }^{8}$

Nevertheless, the increase of the inflow of immigrants does not automatically lead to more restrictive policy preferences and more negative-opinion formulations. How the media- and political elite react to refugee reception crisis, which words they use, affects popular opinion around these issues. In relation to this, it seems far too simplistic to merely rely on a narrative of an irrevocable populist wave that displays the same features everywhere, as indicated by Jan-Werner Mueller (2021). Populism is

\footnotetext{
${ }^{6}$ What Ignazi labelled as the "silent counter-revolution", which he associated with the rise of Jean-Marie Le Pen and la novelle droite (the new right) in France in the early 1970s.

7 Those who resist this development are sometimes labelled as losers of modernization who vote for populist parties because they offer promises of turning back the clock, and they feel alienated from the "new" modern development in the scholarly literature (see further discussion in e.g. Hellström 2016: 46f). ${ }^{8}$ In a recent study on the discursive shift in Poland, the authors show a "steep increase of threat perceptions in Poland, in spite of the fact that this country experienced low numbers of asylum applications (Hootegem \& Meuleman 2019: 54). Similar studies have shown a similar development in Romania and Hungary, where appeals of national identity merge with welfare chauvinistic appeals (see e.g. Cinpoeç \& Norocel 2020). These strategies are no longer seen as extreme, i.e. they are overtly and increasingly normalized in political discourse. In many places, there is an exacerbation of welfare chauvinistic appeals, an escalation of securitization fears, and an increased discrimination of migrants and their offspring (Betz \& Johnson 2004; Conversi 2014; Norocel 2017; Ruzza 2009).
} 
context-dependent. Reality displays a far more nuanced picture than any onedimensional narrative of an omnipresent populist wave suggest. ${ }^{9}$

\section{POPULISM AS MYTHOLOGY OF THE PEOPLE}

Populism is frequently used as an insult in political speech (Oudenampsen 2010; Hellström 2016; Stavrakakis 2017). It connotes demagoguery and opportunism and views politics as short-term oriented - politics as form devoid of content (Canovan 2004). At the same time, populism can be seen as a kind of democratic protest, of bringing the people back into politics (Hellström 2016: 59). Herein lies an ambiguity. In the analysis, I embark from the perspective of seeing populism as a particular mythology of the people that is constitutive of the political communication between the representative elites and the people in democratic politics (ibid). ${ }^{10}$

Generally speaking, populism highlights particular ambivalent features of democratic politics. As such, it is neither un-democratic nor extremely nationalistic (Stavrakakis 2017: 18). Populist mobilization is fuelled by either grievances for the people against the elite (economic, political, or the mainstream media) or the values these elites supposedly espouse that sometimes go against the gut feeling (the common sense) felt by the ordinary people. Namely, the opposition is with a kind of moral elite that knows what is best for the people but has long forgotten what the people's true wishes and interests are (see also e.g. Canovan 2002; see Brubaker 2020 for an elaboration of this distinction).

The above can be referred to as the vertical version of the populist divide. It relates to the divide between the people and the elite, whatever this latter category may be. The horizontal dimension alludes to the actual category of "the people" and who should be included in it. Typically, in far-right political ideology, immigrants are excluded from this category. The opposition to immigration can thus often allude to this dimension of the populist divide.

\footnotetext{
${ }^{9}$ In Sweden, previous research has shown how the dominant political leaders (generally the Social Democrats) chose to frame the development from homogeneity to heterogeneity in the formation of the universal welfare state had effects on public opinion formation (see e.g. Schall 2016).

${ }^{10}$ Democracy is a system of governance that is based on the conviction that the legitimacy of governance lies with the sovereign people (Hellström 2016: 59). However, "the people" as such is not a pre-given monolithic category. If it is imagined as such, it certainly poses an immediate danger to democracy. Following this way of reasoning, populism occupies the empty place of power in democratic politics, and pluralism is replaced by populism and a homogenous idea of what "the people" is (Abts \& Rummens 2007), which respects majority rule but disrespects minority right. In this view, populism can be defined as a kind of illiberal ideology (Pappas 2019).
} 
The opposition to immigration can roughly be divided into two parts: economy and culture (see e.g. Hampshire 2013). The former aspect is typically associated with a fierce ethnic competition for scarce resources. Welfare for the natives is pitted against multiculturalism and diversity embracement. The latter aspect conveys arguments that indicate that immigration does not merely pose a threat to financial resources but also pose a threat to our culture; hence, immigrants are not seen as behaving the same way as we do and do not adhere to the same social norms as we (the natives) do.

This paper's analysis engages with the horizontal version of the populist divide. It emphasizes the mythology of the people in populist discourse. In addition, it provides further knowledge on the mythology of the people and acknowledges the story-telling dimension of representative politics.

Narratives of the past and of future visions are essential elements to understand the contemporary dynamic of representative politics. The fear of the people as the uneducated masses suggests that the people need to be controlled and kept in check by responsible elites (Panizza 2005: 15). In a recent article, Elgenius \& Rydgren (2018) show that anti-immigration frames based on ethno-nationalism are fully embedded into national identity construction and should not be held separate.

In general, the mythology of the people can, confusingly, appeal to the lower strata of the (native) population or relate to the populace as a whole. Canovan (1999) distinguishes between three distinctive ways of appealing to the people (see also the discussion in Hellström 2016: 67). First, the appeals to the people could refer to the united people that stand against the (political) elite who threaten to divide the people, causing social fragmentation and intellectual confusion with postmodernist heresy that disrespects and ignores real facts. Second, the people as a category can refer more specifically to our people, to those who naturally belong here - not, for instance, immigrants who come here and commit crimes. Third, Canovan (1999) talks about the appeal to the common people against the educated and privileged cultural elites. This appeal suggests that the views and real interests of the people are ignored and sometimes ridiculed by the cultural elites who, instead of respecting and listening to the experiences of the common people, merely repeat politically correct knowledge. Appeals to the common people suggest that the (cultural) elites do not live in the real world and have therefore lost contact with the everyday concerns and worries of the ordinary citizens.

In sum, anti-immigration claims intersect with appeals to the people as our people, which suggests a tight link between the people and the nation and thus constitutes the horizontal dimension of the populist divide. My immediate focus is not on illuminating who the real populist actors are but on how anti-immigration claims are discursively articulated and embedded in national identity construction as a particular mythology of the people. Populism is here seen as a mode of political representation that aims at bringing the people into politics (Canovan 2002). 
This approach is akin to what Moffit (2020) describes as the discursive performative approach in the study of populism. Before I begin with the empirical analysis of newspaper articles on national identity in the socially conservative periodical Samtiden, I first need to clarify what national myths actually mean.

\section{NATIONAL MYTHS ${ }^{11}$}

In the anthropological literature on "myths", two main strands are often highlighted (Overing 1997: 7). According to the structuralist approach derived from Lévi-Strauss, myths have little value of their own, since their content is devoid of reason and is the opposite of truth. Conversely, in the functionalist understanding, dating back to Durkheim, the focus is less on the content of myths than on the forms that they take and on the function that they perform in the context where they are articulated. In this tradition, myths have a metaphorical value, not necessarily a literal one (ibid.). Following a functionalist understanding of myths, I focus on the rhetorical forms through which national myths are deployed and on the function they perform for the construction of national identity and for political mobilization (Bottici 2007: 15).

The use of political myths is a recurrent social phenomenon in which national cohesion is reproduced through both symbolic representation (e.g. rituals, customs, traditions, and memory-making) and people's "lived experiences" (Stråth 2000). Myths provide the plot through which community identity is formed (ibid). In the Nordic countries during the twentieth century, it was primarily the social democratic parties that monopolized the meaning of the nation (see Linderborg 2002; Schall 2016; Hellström 2016; Bergmann 2017). In Sweden, for example, the Social Democratic Party gradually shifted from "class" to "people" in its rhetoric - a move that reverberated with popular notions of "Swedishness" (Hellström et al. 2012) and accorded in much with previous bourgeois historiography. ${ }^{12}$ In fact, the Social Democrats inherited largely the same myths about war heroes, founding fathers of the nation, and national writers of great repute. Rather than replacing them, they set about framing these myths in accordance with their own political ambitions.

Political actors ascribe significance to certain narratives of the past (Bottici 2007: 14). Political myths are thus not simply fictitious legends (cf. Kearney 2003); they are not just tales told and retold about our common past. National myths have repercussions on how we view a society and how we demarcate its extent, who belongs to the people and who does not. In this regard, they may fulfil an ideological function.

\footnotetext{
11 The theoretical discussion on "National Myths" has been collected in a partly revised form from Hellström and Pettersson forthcoming).

${ }^{12}$ In a Nordic political context, the term "bourgeois" (borgerlig in Swedish) is not pejorative. It simply refers to the non-socialist parties. Thus, supporters of these parties routinely refer to themselves as bourgeois.
} 
In the analysis, the articulation of anti-immigration claims receives meaning in relation to the function of national myths in practice. Populism seen as the mythology of the people intersects with national identity construction. Myths can serve different ideologies by shaping the constitutive values and collective memories of actual (national) societies and by helping to maintain their societal order or, as in this case, making sense of anti-immigration claims.

In sum, national myths are not merely fake beliefs; rather, they constitute the storytelling dimension of representative politics and provide meaning to the political rhetoric employed in Samtiden's articles.

Even today, various political actors continually reproduce the mythological features and symbolic regimes of the nation (Elgenius 2011, 2015). The nation's history forms an important bond of loyalty between the native population and the state (Megil 2011). In nationalist political discourse, the forms of commemoration - the ways in which national myths are presented - constitute these bonds of loyalty. How anti-immigrations claims are articulated is embedded in symbolic regimes of national identity construction. In the analysis, the material on empirical regimes are organized around three themes (golden age, identity, and conflict), which will be explained in detail below.

I use the aforementioned three themes as heuristic tools drawn from the social-science research on nationalist rhetoric, especially in the area of discursive analysis (see e.g. Billig 1995; Calhoun 2009; Potter \& Wetherell 1987). In this tradition, the nation is conjured, made, and reproduced on a daily basis. What is normal to say in a given time and place is subject to change and influenced by how nationalist claims are manifested in practice. For instance, appeals to the common people are articulated as particular ideas of a distinctively national common sense. In this process, the nation thus becomes naturalized and defines what is normal to say and do. In brief, anti-immigration claims are based on a particular mythology of the people inherent in national identity construction.

\section{Golden age}

In the rhetoric of the radical right, narratives of what makes a given nation special often rely on the story of a golden age from which modern society has fallen and which needs to be restored (e.g. Boros 2018). As the prominent nationalist scholar Anthony D. Smith (1997: 42) famously put it, "[A golden age constitutes] a standard of heroism, glory and creativity, which subsequent ages fail to match." Invocations of such a past gain resonance from popular notions of belonging together in an earlier more homogeneous (national) society.

The image of a golden age evokes a time when the nation was "at its best" - when it constituted a clearly delimited space of culturally similar individuals: a heartland. According to Taggart (2000: 95), the concept of the heartland signifies "the positive aspects of everyday life". It is an image constructed retrospectively of an ideal world - a vision derived from the past and projected on to the present (ibid: 95-98). The heartland 
signals a deep sense of community, of horizontal comradeship, among "the virtuous people". In this imaginary, the native people share proprietary rights to their land. This involves belief in a deep and continuous past, and it reflects deep scepticism of - at times outright opposition to - the extension of such rights to newcomers perceived as "unworthy" (Norocel et al. 2021; Norocel et al. 2020). Accordingly, what is depicted as "our people" in these claims demarcates who should be included in articulated visions for restoring the nation's golden age in the future.

\section{Identity}

Canovan (2004: 251) argues that "it is the invocation of political myths of past foundation and future redemption that enables the ordinary people to assume, through common action, the role of 'popular sovereign'". Indeed, leaders who speak in the name of the people often use political myths to bolster their mandate (Reicher \& Hopkins 2001). In other words, collectively recognized legends and myths can be deployed in political rhetoric to (re)construct a sense of shared identity among "the people" and the nation (ibid.) - a sense of identity that, as Lévi-Strauss would put it, attains its meaning at the level of the "unconscious" (see also Overing 1997: 9). In such rhetoric, with its antagonistic division between "us and them", the construction of an inherently virtuous common identity for "us" is at least as important as the construction of a negative common identity for "them" (Reicher et. al. 2008; Pettersson 2019; Verkuyten 2013).

\section{Conflict}

A long-lasting and dominant dimension of conflict in Nordic politics has been that between labour (left) and capital (right) (Hellström 2016). Other cleavages, such as between urban and rural or between religious and secular, have arguably been less determinative of party-political preferences in the Nordic countries (although, as we shall see below, the urban/rural divide has been of relevance in, for instance, Finland). However, increasingly salient socio-cultural issues pertaining to the EU, migration, gay marriage, and the like do not map neatly on to the classic left/right divide (e.g. Jungar \& Jupskås 2014). Some scholars portray these changing features of mainstream politics as a shift towards socio-cultural questions (Ellinas 2010: 26); however, it can be argued that the traditionally dominant socio-economic cleavage structure has always been enmeshed with cultural matters and cannot easily be separated from cultural conflicts and identity issues (Norocel et al. 2020). 


\section{ANALYSIS}

During and after the refugee crisis of 2015, the Swedish media environment has grown more permissive towards the SD. If almost all newspapers and tabloids had previously united in a show of repugnance against the SD (Hellström et al. 2012), the discourses on immigration politics have now become much more divided (cf. Strömbäck et al. 2017).

However, the explicit anti-immigrations views had previously referred to social media (e.g. Facebook groups and more extreme Internet outlets) or to the commentary field under the opinion pieces or news articles in mainstream press, which were almost all "independently liberal". In the fourth wave, there are many more opportunities to voice anti-immigration concerns, in respectable forums as well. Extreme views have become much more mainstream these days.

Samtiden is a stand-alone news site with a socially conservative ideological platform. It is owned by the SD, and its articles, normally, are congruent - although not identical - with the party line. The first editions came out at the end of 2014. Initially, some conflicts arose concerning the relation between journalistic freedom and the party. Since 2016, Dick Ericsson has acted as the editor-in-chief, and Samtiden's ambition has been to stimulate a conservative ideological debate.

The selection of articles for this paper is based on the search word "national identity" in the Samtiden database. This search resulted in 115 articles, divided by the genres presented in the table below:

Table 1. Genres of the articles published in Samtiden 2016-2019. Search word: National Identity

\section{Genres of the articles published in Samtiden 2016-2019, search word: National Identity}

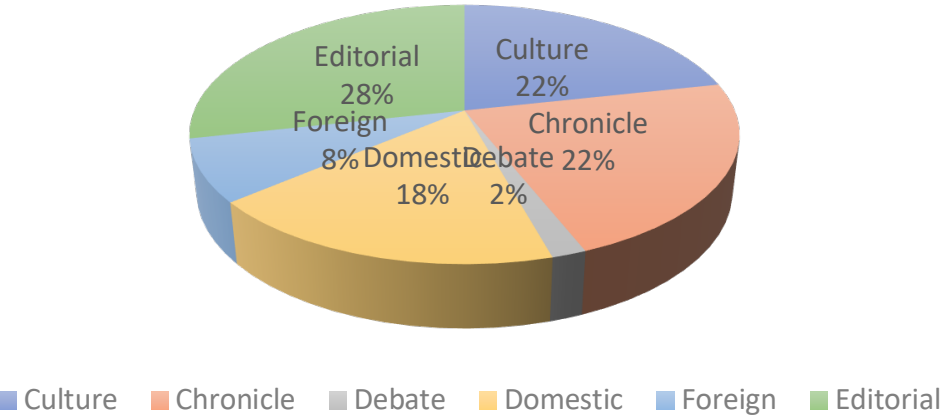

In this outlet, the experiences of problems with the current immigration and integration policies are articulated as political messages. My research focuses on how this is done, not on the extent to which these claims are right or wrong (cf. Åkesson 2018: 26-28). 


\section{Golden Age}

The building of the universal welfare-state after the Second World War involved a series of social reforms to improve the living standard of the common man. Foreign workers were recruited to fill labour shortages in the growing industrial and service sectors. From the mid-1970s onwards, immigration to Sweden changed character and increasingly included refugee migration. The golden age in the analysed material corresponds to the period after the Second World War before the refugee migration kicked off. This period is envisioned as a paradise lost, epitomized in the People's Home metaphor. In populist discourse, this metaphor combines cultural conformism and social cohesion (Hellström 2016: 94). The People's Home is a familiar concept that brings emotive appeals for "our people" (ibid: 95). The mythology of the people thus conveys a vision of a homogenous citizenry of Swedish society after Hitler but before refugee immigration.

The references to remembering a homogenous past occasionally go even further back in Swedish history. These references to the (distant) past in the articles serve the purpose of painting the recent past (Swedish society with hardly any refugee immigration) in bright colours, which stands in contrast to contemporary turmoil. In addition, these references to the past emphasize a common spiritual foundation that forms the basis of the transformation of Swedish society into a veritable "People's Home" (Norocel et al. 2021; Norocel et al. 2020; Hellström 2016). In the articles, there is a noticeable emphasis on a common spiritual foundation for the realization of the People's Home. For instance, in an article about the expenditure movement in the late nineteenth century, references are made both to the historical period of national romanticism and to the golden age in the recent century - namely, the period of the People's Home in its heydays. The ideals of cultural conformism show a historical continuity, with roots that go back to the nation's past; hence, the articles show that the spiritual foundation of successful policy reforms have a distinctively national heritage. One such ideal is the focus on family (not the individual) as the smallest common denominator, which can be traced back to the expenditure movement in the late twentieth century (Samtiden 13 October 2019). This Swedish movement was mobilized to counter the then mass-emigration to the United States (see the prologue), but its ideals have also been fundamental elements in the foundation of the Swedish society after the Second World War.

In a review of Jimmie Åkesson's (party leader of the SD) book on the modern People's Home, Dick Erixon (editor-in-chief of Samtiden) explains that "the People's Home sets the frames for a society in a global world" (Samtiden 25 July 2018). According to Erixon, the Social Democratic Party already back when it was led by PerAlbin Hansson (party leader between 1932 and 1946) both maintained the ideals of 
the Swedish society rooted in conservative ideal and deviated from these ideals in the acceptance and realization of the experiments of racial biology and the forced sterilizations (ibid). Apart from these terrifying examples of departure from the original People's Home idea, the "old" Social Democrats nourished such ideals as national virtues (i.e. humility, diligence, loyalty, and duty) that underpinned the necessary social reforms which the SD now seeks to implement. In another editorial, Dick Erixon (Samtiden 4 October 2017) argues:

What the Swedish Democrats today stand for is the protection of welfare, which requires a national demarcation of who is covered. No other party recognizes this fact right now. Instead, the established parties play with cosmopolitan utopian ideas about a boundless world, even if these require the abolition of Swedish welfare. ${ }^{13}$

The vision of the People's Home as the Swedish society implies an ambition to restore the nation into a People's Home in the future. In line with this argumentation, the "old" Social Democratic leaders are the heroes of the nation, whereas the "new" Social Democratic politicians are the traitors of the nation, diluting the promises to serve the people they claim to represent (Hellström \& Nilsson 2010). This way of reasoning suggests that the new People's Home party in Swedish politics is the Sweden Democrats. On 1 May 2017, Labour day, Dick Erixon gives voice to this opinion in an editorial:

On May 1st, traditional messages from the labour movement are brought to life. But they have no bearing on current politics, where they rather raise identity politics, "racialization", and radical feminism instead of defending the working people's conditions. In Sweden, Per Albin Hansson was able to build the people's home, a conservative political idea that was merged together with social-political reformism. Social democracy abandoned the class struggle for consensus, abandoned internationalism for a national perspective. ${ }^{14}$

\section{Identity}

The emphasis on identity in populist discourse provides a means to counter the current individualization prevalent in society, meaning that populist collective values expand beyond our narcissistic selves. These values, as we learned, have roots that go long back into Swedish history. The collective identity of being Swedish is anchored in a long Swedish national tradition; thus, it is not something that can be acquired easily by the newcomers (who do not share our memories of common roots). Furthermore, the values associated with Swedishness cannot be taught as an abstract principle but have

\footnotetext{
${ }^{13}$ Own translation

${ }^{14}$ Own translation
} 
to be experienced on a daily basis. In the cultural pages (Samtiden 10 April 2015), Dick Erixon claims:

We conservatives value our freedom, not because it is an abstract property of the abstract individual but because it is a tangible and historical achievement, the result of centuries of civil discipline and a sign of our restrained respect for the law of our country.

A bit further down in the article, he makes references to the philosopher Robert Scruton, who argues that conservatism is needed now more than ever since the economic order needs to rely on a higher moral order in order to function:

Adam Smith and David Hume made it clear that the market, the only known solution to the problem of economic coordination, is due to a moral order that emerges from below in which people take responsibility for their own lives, learn to respect agreements, and live in justice and solidarity with their neighbours. ${ }^{15}$

In general, the debate about the nation must rely on a proper historical basis, which is not always the case today (Samtiden 11 August 2015). The individual does not exist in a void; he or she acquire identity through others. What makes Swedes special is today threatened by a massive intake of others who have not experienced our unique traditions, the argument goes. Without these roots, we put into jeopardy, for instance, our natural sense of popular justice (see the section above). Populist discourse has used national values to negotiate a particular Swedish perspective in co-operation with other states, but with contemporary heavy demographic transformations in the Swedish society, these values are at risk (Samtiden 23 September 2015):

Sweden has always had a constructive cooperation with other countries and at the same time retained its national identity, but the mass immigration of recent decades has nothing to do with the responsibility that previous generations of politicians have had for Sweden and that has always historically influenced the views and values of our country's elites on the migration issue. $^{16}$

According to Erixon, without a feeling of belonging together in separable national communities, we run the risk of conflating individual freedom with egoism; hence, there is a need for a common identity. Dick Erixon (Samtiden 19 November 2017) develops on this idea:

Freedom without common community feelings creates egoism. Freedom without attachment to the surrounding society results in estrangement, alienation, and indifference to other people in

\footnotetext{
15 Own translation

${ }^{16}$ Own translation
} 
society. Freedom without a national story leads to distrust, polarization, and permanent political wars.

The old Social Democratic leaders understood the value of appreciating a common identity from below in society to prevent individual freedom from degenerating into pure egoism (see section above). In other words, they understood the value of nationalism and had pride in their own nation. Further, the traditional mainstreamright recognized the benefits of acknowledging community feeling and not merely individual freedom. In an editorial dated 21 November 2018, Dick Erixon refers to the former leader of the liberal-conservative party Moderaterna, Gösta Bohman (party leader between 1970 and 1981) and concludes:

[T] he national community is necessary for a welfare state that can provide basic security, especially for those who do not have their own resources as backup. Without nationalism, no tax revenue to the state. Without nationalism, no democracy where everyone has an equal voice.

According to this reasoning, the old party leaders from both the right and the left understood and appreciated the need for culturally similar individuals to belong to separable national communities. The basic opposition in populist discourse is between the people and the elite, not necessarily between the left and the right. What the contemporary elites, on both sides of the political spectrum, fail to recognize is this basic need emanating from a singular mythology of the people. Consequently, they dilute the promises of a national people and resort to emphasizing cosmopolitan dreams, obscure academic theories, and abstract ideals of world citizenship (Samtiden 29 July 2016): "This establishment is characterized by a an airy-fairy, socialconstructivist ideology, where a loose idea of a 'world citizenship' is believed to be able to replace national identity. ${ }^{17}$ Among the parliamentary parties in contemporary Swedish politics, only the SD has realized this to be the case (Samtiden 22 February 2016):

And among the eight parties in the Riksdag [The Swedish parliament], only the Sweden Democrats even have the ambition to preserve a society with something like a common national identity, common cultural codes and a mutual social contract.

\footnotetext{
${ }^{17}$ Own translation
} 


\section{Conflict}

In the development of the universal welfare state, social reforms of, for example, daycare and parental leave were implemented and facilitated to allow more men and women to join the workforce. These socio-economic reforms also brought repercussions on socio-cultural values (such as individual rights and family values, gender equality, and attitudes towards gay-marriages). In 1995, when Sweden became a member of the EU, the debate around national sovereignty versus international solidarity was high on the political agenda.

The confrontation between progressive and conservative values is currently much debated everywhere. This conflict cuts across traditional partisan cleavages, and it cannot easily be connected to either side. This value-confrontation also lies at the forefront of many discussions in the conservative milieu. In an editorial dated 28 July 2019, Dick Erixon recounts some prevalent messages from a conservative conference held in Washington earlier in July 2019. When recounting the message communicated by Cristoper de Muth from the think tank American Enterprise Institute, Erixon is lyrical and makes references to contemporary Swedish politics:

\footnotetext{
In Sweden, we see the same arrogant denial of natural restrictions in the migration policy pursued for decades. The ruling parties (from $\mathrm{M}$ to $\mathrm{V}^{18}$ ) have deliberately allowed hundreds of thousands of people from foreign civilizations to come to Sweden - without having a plan for housing, schools, healthcare, social care, or a police force that can handle people from significantly more violent cultures.
}

The message is that we rely on each other to handle real turbulence. If the outside world appears as chaotic and violent, we should not import this here but help them in their heath instead. The traditional parties' refusal to see these problems clearly is a revolt against reality, the argument goes. In Sweden, the governing parties no longer realize that the Swedish society (as any national society) rests on homogeneity, not hetereogeneity (Samtiden 8 November 2018):

Since Sweden as a nation has historically been a homogeneous area and has had a white population, the whole country constitutes a provocation against the racist beliefs of intersectionalism.

Airy-fairy academic theories and progressive ideals stand against national ideals of a belonging together in separable nations. This conflict line predicts a value confrontation in many European countries. This line of reasoning dictates that recognizing the mythology of the people is a permanent revolt against the

\footnotetext{
${ }_{18} \mathrm{M}$ stands for Moderaterna (the leading mainstream right party in Sweden and $\mathrm{V}$ stands for Vänsterpartiet (the left party). Both Moderaterna and Vänsterpartiet are currently in opposition.
} 
traditional elites, who have refused to see the actual problems. Thus, it is a muchneeded reality check and a plea to focus on the issues that truly matter.

\section{CONCLUSIONS}

The development towards the mainstreaming of extremism in Europe takes place both in policy and in discourse. The harsh policy measures that were implemented in Sweden and in several other European countries, especially after the 2015 refugee crisis, have led to a discursive shift - what is normal to say and do in the areas of immigration and integration has changed. Anti-immigration claims are no longer merely isolated to the fringes of the political spectrum; they have become more widely accepted and officially sanctioned.

However, the population remains divided. What actually constitutes the category of "the people" is uncertain and remains a site of political struggle. All ideological articulations of what society ought to look like embark from a particular mythology of the people. Appeals to the people - as either the united people, our people, or the common people - thus concern the fundaments of democratic politics. Analysing this is akin to what Benjamin Moffit has referred to as the performative discursive approach to the study of populism.

In the analysis, I have discussed how anti-immigration claims relate to how national myths are used as appeals to the people to represent an alternative vision of the nation, which in turn relies on a particular mythology of the people. The empirical material is based on 115 articles published between 2016 and 2019 in the socially conservative, nationalist online newspaper Samtiden. I used three themes of national myth making in the analysis.

The first theme is the golden age. In the material, much focus is oriented towards the 1950s and the 1960s in Swedish politics. The metaphor of the People's Home is used to both describe the Swedish society at large and denote the political vision with a (more) homogenous national population, cultural conformism, and universal welfare politics. This is the golden age that many of the articles return to in the articles to refer to a period when the people were united. Appeals to the united people are in the articles contrasted with the contemporary domestic political environment, which is divided and polluted by various political promises.

The second theme is identity. The articles belonging to this category constitute the vertical dimension of the populist divide - namely, the little man against the consensual elite. The message in the articles is that both the mainstream left and the mainstream right have in the past successfully solved fundamental societal problems related to social problems (e.g. crime). This is not the case anymore, the articles often repeat. The common man is not listened to and is completely ignored. Appeals to the common people thus stand against the consensual elite. Consequently, the ordinary voter no 
longer sees any fundamental difference between left and right and should therefor vote for the (radical) underdog instead, according to this rhetoric.

The third theme is conflict. Welfare politics merge with discussions on culturally similar people. National welfare is pitted against multiculturalism: welfare-chauvinism. Welfare should be reserved to the natives - to our people. These claims relate to the horizontal dimension of the populist divide, demarcating who naturally belongs in the category of the people and who does not. Appeals to our people in the articles define which people should be included and excluded.

\section{Epilogue}

The opposition to immigration in Sweden has repercussions on how Swedes view themselves - how they view their national identity. A hundred years ago, Sweden faced an enormous emigration problem. This is seldom talked about. Today, the public discussion is rather about immigration, especially refugee immigration. My study of anti-immigration claims in the online socially conservative newspaper Samtiden reveals how they intersect with national identity construction. These claims derive from a particular mythology of the people; further, they are no longer completely cast to the margins but have gradually become embedded in the political mainstream. Hence, if mainstream political actors, in both the government and its opposition, frequently exclaim that the current situation is out of control, anti-immigration views gain credibility. Extremism becomes mainstreamed.

Nonetheless, the future remains uncertain. The mainstreaming of extremism does not lie on a predetermined path, and what mainstream entails in one national context does not necessarily imply the same thing in another political environment. With this paper, I have shown that contemporary claims regarding immigration are based on narratives of the past that in turn rely on a particular mythology of the people. How we in the future will figure out how to live together in diversity relies on how we envision "the people" in representative democratic politics.

\section{REFERENCES}

Aftonbladet 12 April 2021 ”På 20 år blev invandrarhatet det politiskt normala”, Petter Larsson.

Akkerman, T., de Lange, S.L., \& Rooduijn, M. (Eds.) 2016. Radical Right-Wing Populist Parties in Western Europe. London: Routledge.

Betz, H.-G., \& C. Johnson. 2004. "Against the current - stemming the tide: the nostalgic ideology of the contemporary radical populist right", Journal of Political Ideologies, vol. 9, no. 3: 311-327. 
Bevelander, P. 2011. “The Employment Integration of Resettled Refugees, Asylum Claimants, and Family Reunion Migrants in Sweden”, Refugee Survey Quarterly, vol. 30, no. 1 2011: 22-43.

Bevelander, P. and Hellström, A. 2019. "Pro- and Anti-Migrant Mobilizations in Polarized Sweden”, in Rea, A., Martinello, M., Mazzola, A. \& Meuleman, B. (eds) The Refugee Reception Crisis in Europe (pp. 75 - 94), Bruxelles: Éditions de l'Université de Bruxelles.

Bevelander, P. \& Wodak, R. 2019. "Europe at the crossroads: An introduction" in P.

Bevelander \& R. Wodak (Eds.) Europe at the Crossroads: Confronting Populist, Nationalist, and Global Challenges (pp. 7-22). Lund: Nordic Academic Press.

Boros T. 2018. Progressive answers to populism in Hungary, in F. Stetter, T. Boros and

M. Freitas (eds.) Progressive Answers to Populism. Why Europeans vote for populist parties and how Progressives should respond to this challenge (pp. 15-42). Brussels: FEPS - Foundation for European Progressive Studies / Budapest: Policy Solutions.

Bottici, C. 2007. A Philosophy of Political Myth. Cambridge: Cambridge University Press.

Canovan, M. 2004. "Populism for political theorists?" Journal of Political Ideologies 9 (3): 241-252.

Canovan, M. 2002. "Taking Politics to the People: Populism as the Ideology of Democracy" in Y. Meny (ed.), Democracies and the Populist Challenge (p p. 25-44). Gordonsville: Palgrave Macmillan.

Canovan, M. 1999. “Trust the People! Populism and the Two Faces of Democracy”, Political Studies 47.

Conversi, D. 2014. "Between the hammer of globalization and the anvil of nationalism: Is Europe's complex diversity under threat?", Ethnicities, 14(1): 25-49.

Dagens Arena 8 April 2021 “Orimligt förslag om migration”, Lisa Pelling.

Dagens Nyheter 7 April 2021 “Målet är att invandringen ska vara bra för Sverige”, Ulf Kristersson.

Dahlström, C. \& Esaiasson, P. 2011. 'The Immigration Issue and Anti-Immigrant Party Success in Sweden 1970-2006: A Deviant Case Analysis', Party Politics 19 (2): 343364.

Demker, M. 2014. Sverige àt Svenskarna: Motstånd och Mobilisering mot Invandring och Invandrare i Sverige [Sweden for the Swedes: Resistance and Mobilization against Immigration and Immigrants in Sweden], Stockholm, Atlas.

Ellinas, A. E. 2010. The Media and the Far Right in Western Europe: Playing the Nationalist Card. Cambridge: Cambridge University Press.

Elgenius, J. \& Rydgren, J. 2018. "Frames of Nostalgia and Belonging: the resurgence of ethno-nationalism in Sweden", European Societies 21 (4).

Emilsson, H. 2018. "Continuity or Change? The Refugee Crisis and the End of Swedish Exceptionalism”, MIM Working Paper Series No. 3, 2018. 
Hall, P. 1998. The Social Construction of Nationalism: Sweden as an Example.

Lund: Lund University Press.

Hampshire, J. The Politics of Immigration, Cambridge, Polity Press, 2013.

Hellström, A, Norocel, C. \& Bak-Jørgensen 2020 "Nostalgia and Hope: Narrative Master Frames across Contemporary Europe" in Norocel, C., Hellström, A. and Bak-Jorgensen (eds) Nostalgia and Hope: Intersections between Politics of Culture, Welfare, and Migration in Europe (pp. 1 - 16), Cham, Springer.

Hellström, A. (2016). Trust Us: Reproducing the Nation and the Scandinavian Nationalist Populist Parties. New York: Berghahn.

Hellström, A., \& Bevelander, P. (2018). "When the media matters for electoral performance". Sociologisk forskning, 55(2-3), 215-232.

Hellström, A., and T. Nilsson. 2010. "'We are the Good Guys": Ideological positioning of the nationalist party Sverigedemokraterna in contemporary Swedish politics', Ethnicities 10: 55-76.

Hellström, A. \& Pettersson, K. forthcoming. "The use of national myths in the rhetoric of Nordic populist radical right parties”, in Anders Jupskås \& Ann-Cathrine Jungar (eds.), London/New York: Routledge.

Hootegem von, A. \& Meuleman, B. 2019. "European Citizens' Opinions Towards Immigration and Asylum Policies: A Quantitative Comparative Analysis'” in Andrea Rea, Marco Martinello, Alessandro Mazzola and Bart Meuleman (eds) The Refugee Reception Crisis in Europe, pp. 31 - 54, Bruxelles: Éditions de l'Université de Bruxelles.

Ignazi, P. 1992 "The silent counter-revolution: Hypotheses on the emergence of extreme right-wing parties in Europe", European Journal of Political Research 39: $3-34$.

Jungar, A.-C. \& A. Ravik Jupskås 2014. "Populist Radical Right Parties in the Nordic Region: A New and Distinct Party Family?", Scandinavian Political Studies 37 (3): 215-238.

Kaya, Ayhan (2018). "Mainstreaming of Right-Wing Populism in Europe," in Milena Dragicevic and Jonathan Vickery (eds.). Cultural Policy Yearbook 2017-2018:

Cultural Policy and Populism. Istanbul: İletisim Yayinları. Cultural Policy Yearbook 2017-2018.

Kearney, R. 2003. Strangers, gods and monsters. London \& New York: Routledge. Kitschelt, H. \& Mcgann, A. The Radical Right in Western Europe: A comparative Analysis. Ann Arbour: University of Michigan Press.

Megill, A. 2011 [2008] "Historical Representation, Identity, Allegiance”, in S. Berger, L. Eriksonas and A. Mycock (eds.) Narrating the Nation: Representations in History, Media and the Arts. New York/Oxford: Berghahn Books.

Minkenberg, M. (2017). The Radical Right in Eastern Europe: Democracy under Siege? New York: Palgrave Macmillan.

Moffitt, B. 2020. Populism. Cambridge: Polity. 
Mudde, C. 2019 The far right today. Cambridge: Polity Press.

Mudde, C. 2010. The Populist Radical Right: A Pathological Normalcy, West European Politics, 33:6, 1167-1186

Mudde, C. 2004. “The Populist Zeitgeist”, Government and Opposition 39 (4): 542-563.

Mudde, C. \& Kaltwasser, C. (eds.) 2012 Populism in Europe and the Americas: Threat or Corrective for Democracy. Cambridge: Cambridge University Press.

Mueller, J.-W. 23 January 2021 “All quiet on the populist front?”, Specials.

Norocel, C., Hellström, A. \& Bak-Jørgensen, M. 2020 (eds) Nostalgia and Hope: Intersections between Politics of Culture, Welfare, and Migration in Europe, Cham, Springer.

Norocel, O.C. 2017. Åkesson at Almedalen: Intersectional Tensions and Normalization of Populist Radical Right Discourse in Sweden. NORA: Nordic Journal of Feminist and Gender Research, 25(2): 91-106.

Norocel, C., Saresma, T., Lähdesmäki, T. \& Ruotsalainen, M. 2021

"Performing 'us' and 'other': Intersectional analyses of right-wing populist media", European Journal of Cultural Studies, pp. 1 - 19.

Oudenampsen, M. 2010. "Political Populism: Speaking to the Imagination", in Seijdel, J. (ed.), The Populist Imagination: On the Role of Myth, Storytelling and Imaginary in Politics (pp.6-20). Rotterdam: NAi (Issue of the journal Open, no. 20),.

Panizza, F. 2005. "Populism and the Mirror of Democracy", in F. Panizza (ed.), Populism and the Mirror of Democracy. London/New York: Verso, p p .1-31.

Pappas, T. 2019. Populism and liberal democracy: a comparative and theoretical analysis. Oxford: Oxford University Press.

Persson, H.-P. \& H. Arvidsson. 2011. Med kluven tunga: Europa, migrationen och integrationen. Malmö: Liber.

Pettersson, K. 2019. Freedom of speech requires action.' Exploring the discourse of politicians convicted of hate-speech against Muslims. European Journal of Social Psychology, 49(5), 938-952.

Reicher, S. Haslam, S.A., \& Rath, R. 2008. Making a virtue of evil. A five step social identity model of development of collective hate. Social and Personality Psychology Compass, 2/3: 1313-1344.

Reicher, S.D. \& Hopkins, N. 2001. Self and nation. London: Sage.

Rydgren, J. (Ed.) (2018). The Oxford Handbook of the Radical Right. Oxford: Oxford University Press.

Rydgren, J. \& Meiden, S. Van. 2016, "Sweden, now a country like all the others? The Radical Right and the End of Swedish Exceptionalism", Stockholm, University of Stockholm, Department of Sociology: Working Paper Series No. 25, 2016. 
Ruzza, C. 2009. Populism and Euroscepticism: Towards uncivil society? Policy and Society, 28(1), 87-98.

Samtiden 13 October 2019 'Egnahemsrörelsens poänger håller också idag', Lars F. Eklund

Samtiden 28 July 2019 'De progressivas världsbild är en revolt mot verkligheten', Dick Erixon.

Samtiden 21 November 2018 'Moderaternas vägval: Lär av Bohman!', Dick Erixon.

Samtiden 8 November 2018 'Aktivismen som sporrar hat och motsättningar', Jonas W. Andersson.

Samtiden 25 July 2018 'Hur attraktivt är ett modernt folkhem?', Dick Erixon.

Samtiden 19 November 2017 'Nationell sammanhållning förutsättning för frihet', Dick Erixon.

Samtiden 4 October 2017 'Skulle S och SD kunna regera ihop?', Dick Erixon.

Samtiden 1 May 2017 'Socialdemokraterna har glömt sina rötter', Dick Erixon.

Samtiden 29 July 2016 'Václau Klaus om migrationsvågen i ny bok', Simon O. Petersson.

Samtiden 22 February 2016 'Till alla som tror att "Vi- och Dom" är ett argument mot SD', Thomas Brandberg.

Samtiden 23 September 2015 'När historien blir vilseledande', Uffe Hansson.

Samtiden 11 August 2015 'Debatten om nationen behöver ha bättre historiskt underlag', Dick Erixon

Samtiden 10 April 2015 'Stå upp för frihetens sanna mening', Dick Erixon.

Schall, C. E. 2016. The Rise and Fall of the Miraculous Welfare Machine: Immigration

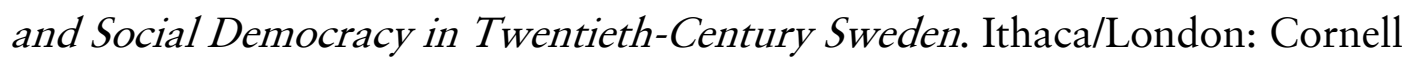
University Press.

Stavrakakis, Y. 2017. How did 'populism' become a pejorative concept? and why is this important today? A genealogy of double hermeneutics, Working Paper no. 6 (Populismus).

Strömbäck, J., Andersson, F. \& Nedlund, E. 2017. Invandring i Medierna: Hur Rapporterade Svenska Tidningar 2005-2015? The Migration Studies Delegation (DELMI), Report 2017: 6).

Strömbäck, J., Jungar, A-C. \& Dahlberg, S. 2016. "Sweden: No Longer an Exception" in Aalberg, T., Esser, F., Reinemann, C., Strömbäck, J. \& de Vresse, C. (eds) Populist Political Communication in Europé (pp. 68 -81). New York: Routledge.

Smith, A. D. 1997. “The 'Golden Age' and National Renewal” (pp. 30 -59) in G. Hosking and G. Schöpflin (eds) Myths \& Nationhood. New York: Palgrave. Statens Offentliga Utredningar (SOU), ”Att ta emot människor på flykt”. SOU 2017

Stråth, B. 2012. "Nordic Modernity: Origins, Trajectories, Perspectives”, in J. P. Árnasson \& B. Wittrock (eds.) Nordic Paths to Modernity (pp. 25 - 48). New York/Oxford: Berghahn Books. 
Suter, B. 2019. "Migration as adventure: Swedish corporate migrant families' experiences of liminality in Shanghai', Transitions: Journal of Transient Migration 3 (1).

Svenska Dagbladet 21 January 2019. "Vi ska inte tillbaka till migrationskrisen 2015", Negra Efendić, available at: https://www.svd.se/vi-ska-inte-tillbaka-tillmigrationskrisen-2015 (accessed in 191117).

Taggart, P. 2000. Populism. Buckingham: Open University Press

Trägårdh, L. 2003. "Crisis and the Politics of National Community: Germany and Sweden" (pp. 75 -109) in L. Trägårdh and N.Witoszek (eds.), Culture and Crisis: The Case of Germany and Sweden. New York: Berghahn Books Verkuyten, M. 2013. Justifying discrimination of Muslim immigrants. Outgroup ideology and the five-step social identity model. British Journal of Social Psychology, 52, 345-360.

Wodak, R. 2019. 'The boundaries of what can be said have shifted': An expert interview with Ruth Wodak (questions posed by Andreas Schulz)., Discourse \& Society $31(2)$

Åkesson, J. 2018. Det moderna folkhemmet: En Sverigevänlig vision. Sölvesborg: Asp \& Lycke. 